\title{
Vandalism as delinquent behavior: Russian and Brazilian experience
}

\author{
Olga Vladimirovna Kruzhkova $^{1 *}$, Irina Vladimirovna Vorobyova $^{1}$, and Anastasiya \\ Plotskaya $^{2}$ \\ ${ }^{1}$ Ural State Pedagogical University, General Psychology and Conflictology Department, Institute of \\ Psychology, Ekaterinburg, Russia \\ ${ }^{2}$ Campinas State University (UNICAMP), Campinas, Brazil
}

\begin{abstract}
The study of vandalism is a topical scientific problem. Except for the scientific interest, wide expansion of destructive activity towards the material environment of a modern city suggests study of legal regulation of vandalism. The goal of the article is to find the national specific character of legal representation and regulation of vandal activity of citizens from Russia and Brazil that has been chosen for a comparative analysis due to the high concentration of vandal damages in Brazilian cities. To achieve this goal, we carried out an analysis of the Criminal Code of the Russian Federation, The Code of the Russian Federation on Administrative Offences and the Criminal Code of the Federal Republic of Brazil, Law 9.605, Law 12.408, Law 2.848 of the Federal Republic of Brazil, etc. The use of the comparative-legal method contributed to the identification of the qualification of vandalism signs as delinquent behavior. We conduct an analysis of the scientific literature describing the basics of understanding vandal behavior and its legal regulation. Also the statistical data of recent years on the law enforcement practice in relation to vandalism were analyzed. The cultural specificity of vandal activity in Russia and Brazil has distinct features in the legal regulation of this type of delinquent behavior. Brazilian experience in decriminalizing graffiti shows that this approach enables the reduction of the load on the judiciary system. In Russia and Brazil, they actively discuss the declaring of graffiti and illegal street art as a form of art that will result in the transformation of legal norms of regulation of the citizens' vandal activity in a while. The scientific novelty lies in the comparison of norms of Russian and Brazilian legislation referred to vandalism to find out ways of its efficient prevention.
\end{abstract}

Keywords: vandalism, delinquent behavior, legal regulation

\section{Introduction}

They began to study vandalism actively at the end of the 20th century [1-6]. It should be understood as an independent form of human interaction with the material (and non-material) environment, which may have a wide variety of forms: graphic - drawings, signs, street art, graffiti; destructive - partial (or complete) elimination, destruction of objects (their

\footnotetext{
* Corresponding author: galiat1@yandex.ru
} 
elements); ideological - destruction or transformation of religious sites, monuments, historical and cultural heritage sites.

Graphic vandalism is the most debating form of vandalism in the city. Illegal graffiti, as well as other forms of vandal damage to the environment, have their own cultural specific character, associated not only with the value and sense bearing goals of vandals, but also with traditions, norms of behavior and many other aspects of the life of a separate urban community. Legal regulation of vandal activity of citizens and, in general, understanding of vandalism as delinquent behavior is a very significant factor.

The goal of this article is to find the national specific character of legal representation and regulation of vandal activity of citizens from the Russian Federation and the Federative Republic of Brazil that has been chosen for a comparative analysis due to high concentration of vandal damages in Brazilian cities.

\section{Methods}

To achieve the goal, legislations of the Russian Federation (The Criminal Code of the Russian Federation, The Code of the Russian Federation on Administrative Offences) and the Federative Republic of Brazil (The Criminal Code of the Federative Republic of Brazil, Law 9.605, Law 12.408, Law 2.848, etc.) were analyzed. A comparative law method was used to identify signs of qualifying vandalism as delinquent behavior. The analysis of scientific literature on the topic of vandal behavior and its legal regulation, analysis of statistical data on law enforcement practice was also carried out.

\section{$3 \quad$ Results}

In the humanities and social sciences, vandalism is understood as a form of the subject's impact on objects of the urban environment, expressed in the subject's desire to change its current state without relevant sanctions from another subject having legal rights to these objects (its owner or manager) [7]. However, within the legal framework, vandalism as delinquent behavior in different countries is understood in different ways, highlighting the cultural and national specifics of its acceptability in a particular society.

Brazil is an interesting example, where vandalism is widely spread. It is important to note that traditionally Brazil is a country with very high protest activity. Activists can use property destruction tactics as a form of protest. It often happens during disorders, but it can also be a single event, for example, animal activists destroy the property owned by farmers, biotech companies, and research institutions (it is often referred to as eco-terrorism).

In Brazil, the law on punishment for painting - pichação is based on the law on environmental crimes: Law 9.605 Article 65 "Graffiti or other means of desecrating urban buildings or monuments" (wording of Law No. 12.408 of 2011); and provides for sanctions in the form of arrest for a period of three months to one year and a fine. If the act is performed with a monument or object from the list of objects of artistic, archaeological or historical value, they administer the punishment in the form of arrest for six months to one year and a fine [8].

In addition, protection of public interests referred to the property makes the content of Article 163, III of the Criminal Code, which states that "destruction or damage to someone else's property, as well as leaving it abandoned" is a crime, while the criminal legislation also provides for a qualifying criterion for this kind of socially dangerous acts when it is done "against property of the Federation, state, municipality, concession company rendering public services or a mixed capital company" [9]. The legal disposition defines two aspects of 
public interest: expression of the inherent public value (objective) and expression of the subjective value of the economic activity of the country in favor of the society.

Brazilian law distinguishes the act of vandalism (pichação) from graffiti, which was decriminalized in Brazil in 2011 by the Federal Law No. 12408/2011 [10]. However, the law also prohibits the sale of aerosol paints for children under 18 years (when purchasing a product, you must present an identification document, and the invoice must contain the following information: PICHAÇÃO É CRIME, i.e. "graffiti is a crime" [8]).

In Russian legislation, in the Criminal Code of the Russian Federation, since 1997 a separate article has been introduced that defines elements of this crime, where vandalism is considered as desecration of buildings or other structures, damage to property on public transport or in other public places [11], which can be punished with a fine of up to forty thousand rubles, as well as an arrest for a period of up to three months. If vandalism is committed by a group of people, as well as out of political, ideological, racial, national or religious hatred or strife, or out of hatred or strife towards any social group, they may be punished by restrain, as well as imprisonment for a period of up to three years [12]. This article regulates an extremely narrow list of items of vandalism - damage to buildings or structures, as well as objects of the transport system. Destruction or deformation of objects that do not belong to the specified categories (for example, objects of nature, historical monuments, gravestones, etc.) is out of vandalism as a crime and is classified under other articles of the Criminal Code of the Russian Federation. Difficulties in qualifying vandalism are also related to the lack of defining norms and definitions of such a term used in the wording of Article 214 of the Criminal Code of the Russian Federation as "public space" [13].

When qualifying vandal actions towards the private property, Article 7.17 of the Code of the Russian Federation on Administrative Offences is applied - destruction or damage to someone else's property, if these actions did not cause significant loss. Under this article, the destruction of someone else's property entails a fine in the amount of three hundred to five hundred rubles. Also, Article 20.1 of the Code of the Russian Federation on Administrative Offences "disorderly conduct" is effective, that is, a violation of public order, showing obvious disrespect for society, accompanied by destruction or damage to someone else's property, which entails a fine in the amount of five hundred to one thousand rubles. If these actions are associated with disobedience to a legal request of an official or a person performing duties to protect the public order or suppress the disturbance of public peace, a fine will be increased from one thousand to two thousand five hundred rubles [14]. It is worth noting that fines often cannot cover the damage caused by a vandal and compensate for the costs of the state or the owner for the elimination of damage and restoration of the vandalized object.

Thus, the legislation of the Russian Federation regulates longer terms of punishment for vandalism, although there are certain discrepancies in the legal acts of Russia and Brazil both in qualifying features, the objective side of vandalism, and the subject of vandalism.

\section{Discussion}

Vandalism, as an act qualified by the legislation of both the Russian Federation and the Federative Republic of Brazil, has an antisocial nature, damages not only material objects, but also undermines the institute of property, accompanies and contributes to disturbance of public peace [15]. Nevertheless, there are cultural and regulatory differences in understanding of vandalism and in the attitude towards its certain forms.

Thus, according to the publicistic position of Brazilian authors, the practice of graffiti conquered people who had made illegal graffiti before, which enabled to legitimize street artists who had previously presented their works in the urban environment in an illegal 
way [16]. Decriminalization of graffiti in Brazil resulted in permission to apply it even to private property, subject to the consent of the owner, permission from the competent authority and compliance with the laws on preservation of national historical and artistic heritage. Following all these recommendations, graffiti in Brazil cannot be classified as a criminal act now.

In Russian society, they also discuss the difference between vandalism and graffiti (street art), the recognition of objects of illegal street art as art objects [17], but in the legal regulation, both typical tagging and graffiti are considered equally as an offense or criminal act.

However, the growing number of cases of vandalism in Brazil against public property and the increased costs of reconstruction of public property [18] indicate that the goals of punishment (prevention of destructive behavior and resocialization of those who have already committed it) are not being achieved in practice. The researchers note that the potential restriction of freedom for an act of vandalism committed against public property has not proved its ability to prevent this kind of crime. The reasons are as follows: legal nihilism, lack of distinct enforcement mechanisms, and a sense of impunity. This is also facilitated by frequent acquitting judgments for vandalism, delivered on the principle of the insignificance of the act and its consequences.

In Russian law enforcement practice, Article 214 of the Criminal Code of the Russian Federation is used quite rarely. Thus in 2019, 193 persons were convicted in Russia under this article (145 - under part 1, 48 - under part 2), while the sentence of imprisonment was administered only towards eight persons charged with vandalism (3 cases of imprisonment, 5 cases of a suspended jail sentence). In other cases, measures of constraint were applied to insane persons ( 82 cases), fines (71 cases), corrective labour and compulsory community service (30 and 37 cases, respectively) [11]. Despite the high frequency of damage to the urban environment in Russian cities, the practice of punishment for destruction of material space is insignificant, which indirectly contributes to the expansion of vandalism as a form of delinquent behavior. Particularly alarming is the fact that often destructive ways of human interaction with environmental objects are a kind of pre-delinquent or pre-criminal form of behavior, which, under certain circumstances, is transformed into a person's conscious choice to break the law [20].

\section{Conclusion}

The cultural specificity of vandalism in Russia and Brazil has distinct features both in the demonstration of vandalism and in legal regulations of this type of delinquent behavior. Brazilian experience in decriminalizing graffiti shows that this approach enables reduction of the load on the judiciary system, but has a questionable resource in terms of vandalism prevention. On the other hand, both in Russia and in Brazil they actively discuss the declaring of graffiti and illegal street art as a form of art that will result in the transformation of legal norms of regulation of the citizens' vandal activity in a while.

The research was funded by the grant of the Russian Science Foundation (project No. 17-18-01278).

\section{References}

1. L.S. Vatova, Sotsialno-psikhologicheskie osnovaniya molodezhnogo vandalizma i ego profilaktika [Socio-psychological foundations for vandalism among youth and its prevention] (Narodnoe obrazovanie, Moscow, 2007)

2. E.N. Volkova, E.A. Mititsina, Vestnik of Minin Univ. 8(3), 6 (2020). https://doi.org/10.26795/2307-1281-2020-8-3-6 
3. I. Golovakha, Sociol.: Theory, Methods, Market., 2, 64-77 (2004)

4. K.V. Zlokazov, Legal Order: Hist., Theory, Pract. 3(22), 79-83 (2019)

5. F. Trovo, E. Griguol, Chimica Oggi. Chemistry Today 35(4), 42-46 (2017)

6. J.Q. Wilson, G.L. Kelling, Atlantic Monthly, 249, 29-38 (1982)

7. O.V. Kruzhkova, I.V. Vorobyeva, R.Yu. Porozov, B. Zarbova, The Ed. and Sc. J. 20(10), 95-120 (2018). https://doi.org/10.17853/1994-5639-2018-10-95-120

8. LEI No 9.605, DE 12 DE FEVEREIRO DE 1998, Presidência da República Casa Civil Subchefia para Assuntos Jurídicos. Accessed on: April 14, 2021. [Online]. Available at: http://www.planalto.gov.br/ccivil_03/leis/19605.htm

9. Decreto-lei no 2.848, de 7 de dezembro de 1940. Accessed on: March 23, 2021. [Online]. Available: http://www.planalto.gov.br/ccivil_03/decretolei/del2848compilado.htm

10. Lei no 12.408, de 25 de maio de 2011 Accessed on: March 23, 2021. [Online]. Available: http://www.planalto.gov.br/ccivil_03/_Ato20112014/2011/Lei/L12408.htm\#art6

11. Yu.N. Skuratova, V.M. Levedeva, Kommentarii k Ugolovnomu kodeksu Rossiiskoi Federatsii [Comments to the Criminal Code of the Russian Federation] (Infra-M: Norma, Moscow, 1997)

12. Ugolovnyi kodeks Rossiiskoi Federatsii [The Criminal Code of the Russian Federation]. Accessed on: March 23, 2021. [Online]. Available: https://uk-kodeks.ru/

13. Yu.D. Nalimov, Bul. Kazan Law Instit. of MIA of Rus. 11(3), 297-301 (2020). https://doi.org/10.37973/KUI.2020.41.3.00

14. Kodeks Rossiiskoi Federatsii ob administrativnykh pravonarusheniyakh [The Code of the Russian Federation on Administrative Offences]. Accessed on: March 23, 2021. [Online]. Available: https://koap-kodeks.ru/

15. V.G. Pavlov, Bul. St.-Petersburg Law Acad. 25, 95-100 (2014)

16. G. Lassala, Pixação não é pichação. (ALTAMIRA EDITORIAL, São Paulo, 2010)

17. R.D. Zhmurko, Sc. Rev. 4, 31-33 (2019)

18. F.S. Ramos, F.D.J.U. Paiva, M.G.G.V. Guerra, Revista Facthus Jur. 2(1), 37-53 (2016)

19. Ugolovnoe sudoproizvodstvo. Dannye o naznachennom nakazanii po statyam UK. 2019 god [Criminal process. Information on imposed penalty under the Criminal Code, 2019] Accessed on: March 23, 2021. [Online]. Available: http://stat.xn---7sbqk8achja.xn--p1ai/stats/ug/t/14/s/17

20. M. Stodolska, L. Berdychevsky, K.J. Shinew, Leisure Sc. 41(4), 278-293 (2017) https://doi.org/10.1080/01490400.2017.1329040 